\title{
Inhibitory effect of cimetidine on gastric acid secretion vagally activated by physiological means in duodenal ulcer patients
}

\author{
I. M. SCHÖÖN AND L. OLBE \\ From the Department of Surgery II, Sahlgren Hospital, Göteborg, Sweden
}

SUMMARY Vagal activation of gastric acid secretion by modified sham feeding in six patients with duodenal ulcer produced a peak acid response amounting to $52 \%$ of the peak acid output after pentagastrin stimulation $\left(\mathrm{PAO}_{\mathrm{pg}}\right)$. Cholinergic reflex stimulation of gastric acid secretion by fundic distension in another six patients with duodenal ulcer produced a peak acid response of $45 \%$ of $\mathrm{PAO}_{\mathrm{pg}}$. Intravenous infusion of cimetidine in a dose of $100 \mathrm{mg} / \mathrm{h}$ markedly inhibited the acid sham feeding response by $90-100 \%$ and almost abolished the acid response to fundic distension. The results suggest that gastric acid secretion evoked by physiological vagal activation in man is profoundly inhibited by $\mathrm{H}_{2}$-receptor blocking agents.

The existence of two types of histamine receptors, $-\mathrm{H}_{1}$ and $\mathrm{H}_{2}-$ has been established (Black et al., 1972). The $\mathrm{H}_{2}$-receptor antagonists of thiourea configuration (burimamide and metiamide) markedly inhibited gastric acid secretion stimulated by histamine or gastrin but seemed less effective in inhibiting the acid secretion evoked by cholinergic stimuli (Black, 1973). Metiamide inhibited by $40 \%$ at $1 \mathrm{mg} /$ $\mathrm{kg}$ intravenously and by $90 \%$ at $10 \mathrm{mg} / \mathrm{kg}$ the acid response to electrical vagal stimulation in cats (Bauer and Brooks, 1976). Metiamide furthermore inhibited by $70-80 \%$ at the dose of $1 \mathrm{mg} / \mathrm{kg}$ intravenously the acid response to sham feeding in the dog (Sjödin, 1976). The mode of action of $\mathrm{H}_{2}$-receptor antagonist on acid secretion produced by stimuli other than histamine is poorly understood. Metiamide did not inhibit acetylcholine-induced acid secretion in the isolated kitten fundic mucosa (Tepperman et al., 1975). In the cat the $\mathrm{H}_{2}$-receptor blockade with metiamide was additive to the inhibitory effect of atropine on maximal acid secretion evoked by pentagastrin (Thompson et al., 1975). The antagonism of metiamide on pentagastrin-stimulated acid secretion in man seemed to be of both competitive and non-competitive type (Thjodleifsson and Wormsley, 1975). The acid secretion evoked by local chemical stimulation of the oxyntic cell area could not be abolished by metiamide (Konturek et al., 1976). Acid secretion stimulated by theophylline or by dibuturyl cAMP was not inhibited by $\mathrm{H}_{2}$-receptor

Received for publication 6 July 1977 antagonists in animals (Shoemaker et al., 1974). A $\mathrm{H}_{2}$-receptor antagonist has, however, been shown to abolish caffeine-stimulated gastric acid secretion in man (Cano et al., 1976).

A non-thiourea $\mathrm{H}_{2}$-receptor antagonist, cimetidine, has been introduced (Brimblecombe et al., 1975). It seems to have the same antisecretory properties as burimamide and metiamide, including the property of being less effective against cholinergic stimuli (Brimblecombe et al., 1975). Cimetidine is effective after both intravenous and peroral administration and it may be slightly more potent on a molar basis than metiamide, possibly because of a longer circulating half-life (Brimblecombe et al., 1975). In man cimetidine has been shown markedly to inhibit basal acid secretion and the acid responses to pentagastrin, histamine, and a meal (Burland et al., 1975; Henn et al., 1975; Hollander et al., 1975; Cano et al., 1976; Richardson et al., 1976). Cimetidine also inhibited by $75 \%$ the acid response to pharmacological vagal activation by insulin hypoglycaemia in man (Carter et al., 1976).

The present study aimed at determining the effect of cimetidine on acid secretion evoked by physiological vagal reflex stimulation in duodenal ulcer patients.

\section{Methods}

\section{SUBJECTS}

Six men aged 29 to 54 (mean 44) years, all with a long history of recurrent duodenal ulceration, were sub- 
jected to vagal stimulation of gastric acid secretion by modified sham feeding. Endoscopy or $x$-ray examination immediately before the study confirmed duodenal ulceration in four patients, a prepyloric ulcer in one patient, and duodenal erosions in one patient.

Another group of six male patients, aged 27 to 56 (mean 45) years, with previously confirmed duodenal ulceration, were subjected to stimulation of gastric acid secretion by fundic distension. The patients gave consent to the study after receiving detailed information. The study was approved by the Ethical Committee at the Faculty of Medicine, University of Göteborg.

\section{ADMINISTRATION AND DETERMINATION OF CIMETIDINE}

In separate experiments on each patient an intravenous infusion of either cimetidine or saline was administered in a randomised order. After four 15 minute periods of determination of the basal acid secretion, saline or $200 \mathrm{mg}$ cimetidine was intravenously infused at a constant rate for the following 120 minutes. The mean dose of cimetidine was 1.4 $\mathrm{mg} \mathrm{kg}^{-1} \mathrm{~h}^{-1}$ (range 1/2-1.6). Venous blood samples were taken in heparinised tubes for determination of plasma cimetidine concentration. Blood samples were taken twice in the basal period at $\mathbf{0}$ and $\mathbf{3 0}$ minutes before starting the intravenous infusion of cimetidine and then at 90, 120, 180, and 210 minutes. After centrifugation the samples were frozen and stored at $-20^{\circ} \mathrm{C}$ before assay. The determination of cimetidine concentration was carried out by the Biochemistry Department of the Research Laboratories of Smith Kline \& French laboratories. Plasma cimetidine concentration $(\mu \mathrm{g} / \mathrm{ml})$ was determined using high pressure liquid chromatography.

\section{DETERMINATION OF ACID SECRETION}

The experiments were carried out after an overnight fast. The subjects were placed in a semi-recumbent position. A double lumen nasogastric tube (Salem Sump Tube No. 14) was placed with its tip in the antral part of the stomach under fluoroscopic control. The gastric contents were continuously aspirated using a suction pump giving negative pressure $(90$ $\mathrm{mm} \mathrm{Hg}$ ) once per second. Throughout the experiments the stomach was continuously perfused with a phenol red solution $(8 \mathrm{mg} / \mathrm{l})$ at a rate of $225 \mathrm{ml} / 15$ min via a thin polyethylene tube with its tip $5-10 \mathrm{~cm}$ below the cardia. The rather high perfusion volume was used to facilitate the mixing of marker solution and gastric content. The volume and $\mathrm{pH}$ of the collected gastric contents was determined for each 15 minute period by potentiometric titration of $100 \mathrm{ml}$ to $\mathrm{pH} \mathrm{7.0.} \mathrm{The} \mathrm{phenol} \mathrm{red} \mathrm{concentration} \mathrm{in} \mathrm{the} \mathrm{gas-}$ tric contents was determined spectrophotometrically at wave length $565 \mathrm{~nm}$ after filtration (Millipore filter $1,2 \mu$ ) and alkalinisation with $0.4 \mathrm{ml}$ of concentrated $(10 \%) \mathrm{NaOH}$. The known percentage loss of phenol red, assuming that the same percentage of acid had been lost via the pylorus, allowed the amount of acid secreted to be calculated.

\section{MODIFIED SHAM FEEDING}

After two 15 minute periods of intravenous infusion (cimetidine or saline) the patients were given hamburgers and omelette to chew. The patients were not allowed to swallow the food and were encouraged to spit out the morsel and to rinse the mouth with water. The modified sham feeding was extended over 15 minutes. Thereafter acid secretion was followed for nine further 15 minute periods, including four 15 minute periods after the end of cimetidine or saline infusion. Peak acid output was defined as the sum of the two highest consecutive 15 minute periods.

\section{FUNDIC DISTENSION}

A thin-walled rubber balloon connected to a thin polyethylene tube was tied to the nasogastric sump tube with the balloon $20 \mathrm{~cm}$ above the intragastric tip of the tube. The correct position of the balloon was frequently checked by fluoroscopy during the test. To avoid pooling of gastric contents above the distended balloon another aspiration hole was cut in the nasogastric tube at this point. After two 15 minute periods of intravenous infusion (cimetidine or saline) the balloon was slowly filled with $650 \mathrm{ml}$ of air over a period of 15 minutes. The distension was maintained for five further 15 minute periods after which distension was released and acid secretion was determined for four further 15 minute periods.

MAXIMAL ACID RESPONSE TO HUMORAL STIMULI

The peak acid output after stimulation with penta-

Table 1 Individual peak values of maximal acid responses to pentagastrin $\left(P A O_{p g}\right)$ and to modified sham feeding $\left(P A O_{s h}\right)$ in six duodenal ulcer patients

\begin{tabular}{|c|c|c|c|}
\hline Subjects & $\begin{array}{l}P A O_{p g} \\
(m m o l / 30 \mathrm{~min})\end{array}$ & $\begin{array}{l}P A O . g \\
(\mathrm{mmol} / 30 \mathrm{~min})\end{array}$ & $\begin{array}{l}P A O_{s h} / P A O_{p g} \\
(\%)\end{array}$ \\
\hline 1 & $34 \cdot 6$ & $23 \cdot 8$ & 69 \\
\hline 2 & $26 \cdot 7$ & 6.8 & 26 \\
\hline 3 & $29 \cdot 0$ & $14 \cdot 1$ & 49 \\
\hline 4 & $33 \cdot 3$ & $15 \cdot 8$ & 47 \\
\hline 5 & $24 \cdot 5$ & $8 \cdot 6$ & 35 \\
\hline 6 & $21 \cdot 2$ & 19.9 & 94 \\
\hline Mean & $28 \cdot 2$ & $14 \cdot 8$ & 52 \\
\hline SEM & $\pm 2 \cdot 1$ & \pm 2.7 & \\
\hline
\end{tabular}


gastrin (Peptavlon, ICI) or betazol (Histalog, Lilly) was determined in each patient. Pentagastrin was intravenously infused in a dose of $90.8 \mu \mathrm{g} / \mathrm{h}$ for 45 minutes, followed by $298 \mu \mathrm{g} / \mathrm{h}$ for a further 60 minutes in 11 patients. Histalog was given as a subcutaneous injection $(2 \mathrm{mg} / \mathrm{kg}$ body weight) and acid secretion was determined for $2 \frac{1}{2}$ hours in one patient. Peak acid output was defined as the sum of the two highest consecutive 15 minute periods.

STATISTICAL EVALUATION

The Wilcoxon matched-pairs' signed-ranks test was used (Siegel, 1956).

\section{Results}

EFFECT OF CIMETIDINE ON ACID RESPONSE TO MODIFIED SHAM FEEDING

The mean peak acid output after modified sham feeding was $14.8 \mathrm{mmol} / 30 \mathrm{~min}$, amounting to $52 \%$ of mean peak acid output after pentagastrin or Histalog stimulation in the six duodenal ulcer patients (Table 1). Cimetidine markedly inhibited the basal acid secretion in the second 15 minute period of infusion as well as the acid response to modified sham feeding (Fig. 1). In each individual the cimetidine infusion significantly inhibited the acid response $(P<0.025)$ and abolished the acid secretion in the last 15 minute period of cimetidine infusion. Acid secretion reappeared after stopping the cimetidine infusion. The plasma cimetidine concentrations showed a mean concentration of $0.67 \mu \mathrm{g} / \mathrm{ml}$ at 30 minutes after starting the infusion and the mean concentration levelled off to $0 \cdot 98-1.08 \mu \mathrm{g} / \mathrm{ml}$ during the infusion (Fig. 1).

\section{EFFECT OF CIMETIDINE ON ACID RESPONSE TO FUNDIC DISTENSION}

Fundic distension in six duodenal ulcer patients gave a mean peak acid output of $11.2 \mathrm{mmol} / 30$ minutes which was $45 \%$ of the mean peak acid output after pentagastrin stimulation (Table 2). Cimetidine almost abolished the acid response to fundic distension. The inhibition exceeded $96 \%$ in every 15 minute period. The acid secretion did not reappear during the four 15 minute periods after the end of the intravenous infusion of cimetidine (Fig. 2). The inhibition was significant $(\mathrm{P}<0.025)$. The mean plasma cimetidine concentrations were $0.81 \mu \mathrm{g} / \mathrm{ml}$ at 30 minutes after starting the infusion and then remained at 1.05-1.36 $\mu \mathrm{g} / \mathrm{ml}$ throughout the infusion period (Fig. 2).

\section{Discussion}

Vagal activation by adequate sham feeding in duodenal ulcer patients produces a peak acid response amounting to about $55 \%$ of the peak acid response
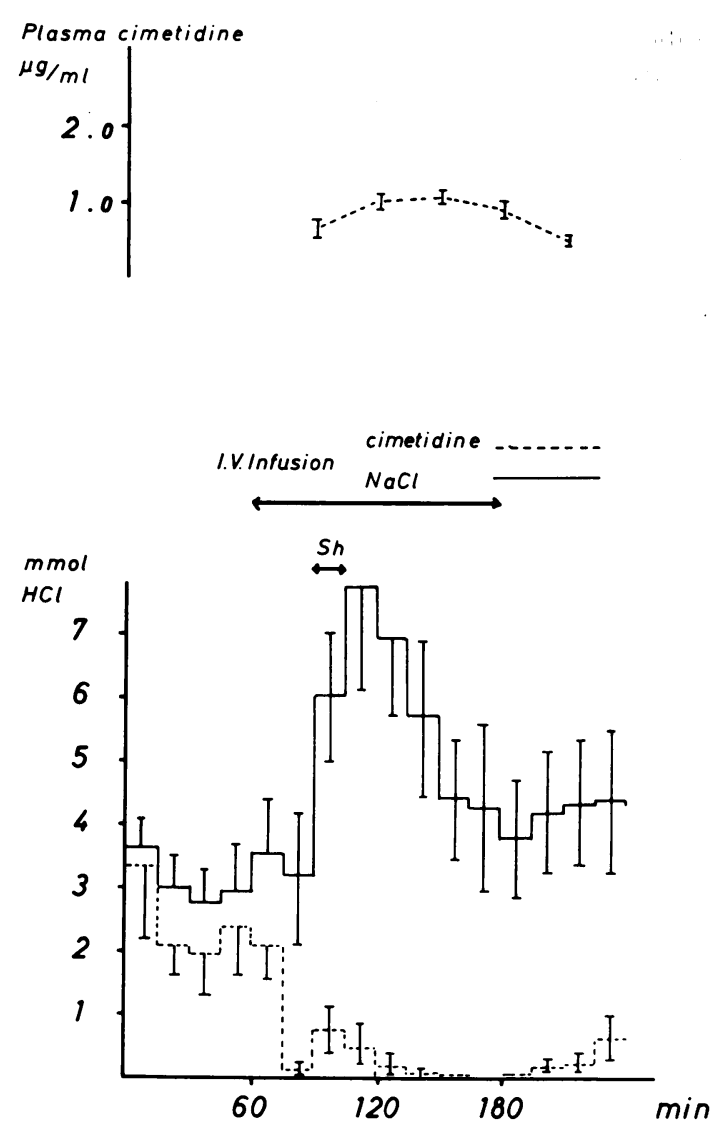

Fig. 1 Mean $( \pm S E M)$ plasma cimetidine concentrations during intravenous infusion of $200 \mathrm{mg}$ cimetidine for two hours and its effect on mean $( \pm S E M)$ basal acid secretion and acid response to 15 minutes modified sham feeding (Sh) in six duodenal ulcer patients.

to pentagastrin stimulation (Knutson and Olbe, 1974a). Gastrin is concomitantly released (Knutson et al., 1974; Mayer et al., 1974) and originates mainly from the antrum (Knutson et al., 1974). The released gastrin contributes to the acid sham feeding response but seems to be quantitatively of minor importance in man (Knutsson and Olbe, 1974a, b). The acid response to sham feeding is abolished by proximal gastric vagotomy in duodenal ulcer patients (Knutson and Olbe, 1973). Consequently the predominating stimulus to acid secretion by sham feeding in man seems to be direct vagal activation of the oxyntic cell area. Fifteen minutes of sham feeding produces near maximal acid response to that stimulus in duodenal ulcer patients (Knutson and Olbe, 1974a). The acid response to modified 
Table 2 Individual peak values of maximal acid responses to pentagastrin $\left(P A O_{p g}\right)$ and to fundic distension $\left(P A O_{f d}\right)$ in six duodenal ulcer patients

\begin{tabular}{llcl}
\hline Subjects & $\begin{array}{l}P A O_{\mathrm{pg}} \\
(\mathrm{mmol} / 30 \mathrm{~min})\end{array}$ & $\begin{array}{l}P A O_{\mathrm{id}} \\
(\mathrm{mmol} / 30 \mathrm{~min})\end{array}$ & $\begin{array}{l}P A O_{\mathrm{td}} / P A O_{p g} \\
(\%)\end{array}$ \\
\hline 7 & 25.9 & $9 \cdot 3$ & 36 \\
8 & 32.8 & 11.7 & 36 \\
10 & 15.7 & 10.0 & 64 \\
11 & 27.8 & 16.1 & 58 \\
12 & 24.0 & 10.2 & 42 \\
13 & 25.3 & 10.2 & 40 \\
Mean & 25.3 & 11.3 & 45 \\
SEM & \pm 2.3 & \pm 1.0 & \\
\hline
\end{tabular}

sham feeding by the 'chew and spit' technique is not significantly different from the acid response to adequate sham feeding (Stenquist et al., 1976). In the present study 15 minutes of modified sham feeding produced a peak acid response amounting to $52 \%$ of the peak acid response to pentagastrin stimulation.
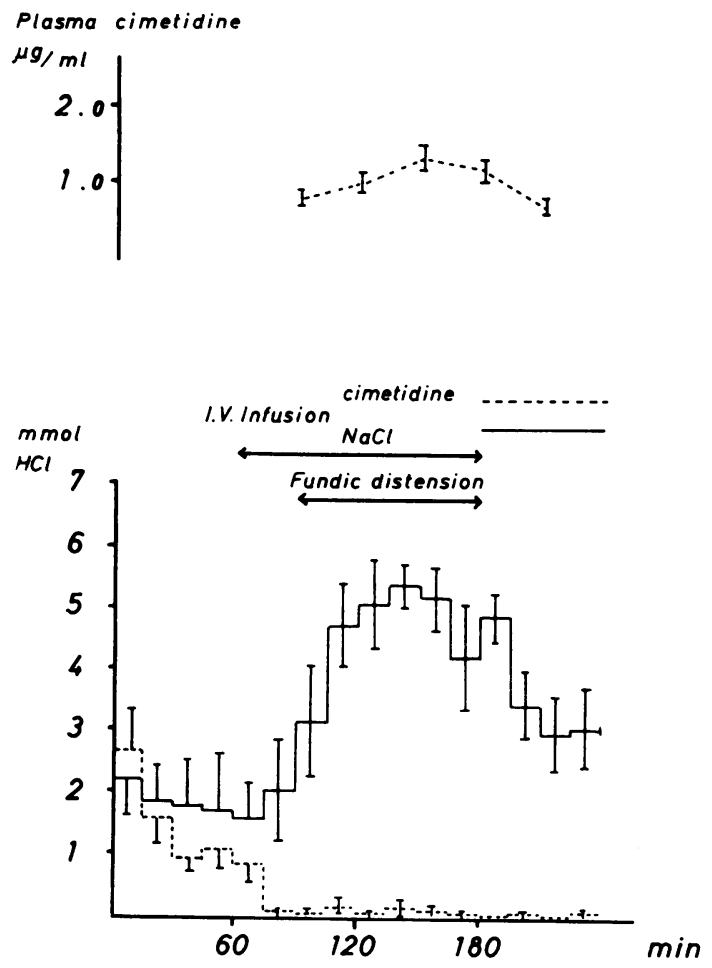

Fig. 2 Mean ( \pm SEM) plasma cimetidine concentrations during intravenous infusion of $200 \mathrm{mg}$ cimetidine for two hours and its effect on mean $( \pm S E M)$ basal acid secretion and acid response to fundic distension by a balloon of $650 \mathrm{ml}$ in six duodenal ulcer patients.
Cimetidine profoundly inhibited the acid sham feeding response by $90-100 \%$. Graded fundic distension is a potent stimulus to acid secretion in man. The peak acid response has been evoked by $600 \mathrm{ml}$ balloon distension reaching about $50 \%$ of the peak acid response to pentagastrin stimulation (Grötzinger et al., 1977a). This acid distension response is evoked by an atropine-sensitive mechanism partially dependent on intact vagal innervation without contribution of any significant gastrin release (Grötzinger et al., $1977 \mathrm{~b}, \mathrm{~d})$. The acid response to fundic distension in man is then most reasonably mediated via cholinergic long vagovagal and short intramural reflex pathways that previously have been established in the dog (Grossman 1961, 1962). In the present study fundic distension by a balloon of $650 \mathrm{ml}$ produced a peak acid response of $45 \%$ of the peak acid response to pentagastrin stimulation. Cimetidine almost abolished the acid response to fundic distension.

Plasma concentrations of cimetidine just above 1 $\mu \mathrm{g} / \mathrm{ml}$ inhibited by more than $90 \%$ the acid responses to sham feeding and fundic distension in the present study. Blood concentrations of cimetidine of 0.4-0.5 $\mu \mathrm{g} / \mathrm{ml}$ have inhibited by $50 \%$ the acid responses to pentagastrin and a meal in man (Burland et al., 1975; Pounder et al., 1976). These data seem to indicate that in man the acid secretion evoked by physiological nervous excitation of the oxyntic gland area is as sensitive to inhibition by the $\mathbf{H}_{2}$-receptor blocking agents as is the acid secretion produced by humoral stimulation. The inhibitory effect observed in the present experiments may not, however, be due solely to $\mathbf{H}_{2}$-receptor blockade, as there is some evidence that at least fundic distension in man elicits stimulatory as well as endogenous inhibitory effects on acid secretion (Grötzinger et al., 1977c). The mechanism of this endogenous inhibitory action is unknown.

This investigation was supported by the Swedish Medical Research Council (Project no 17x-760) and by Göteborgs Läkaresällsakp. Cimetidine was kindly supplied by Dr W. L. Burland of Smith, Kline and French Laboratories, Ltd., Welwyn Garden City, England. The authors wish to thank Miss E. Lindberg, Mrs A. Toving, Mrs B. Nyman, and Mrs M. Öhman for skilled technical assistance.

\section{References}

Bauer, R. F., and Brooks, F. P. (1976). $\mathrm{H}_{2}$-receptor blockade with metiamide-gastric secretion of acid and pepsin and gastrin release during electrical vagal stimulation. Gastroenterology, 70 A-4/862 (Abstract).

Black, J. W., Duncan, W. A. M., Durant, C. J., Ganellin, C. R., and Parsons, E. M. (1972). Definition and antagonism of histamine $\mathbf{H}_{2}$-receptors. Nature (London), 236, 385390. 
Black, J. W. (1973). Speculation about the nature of the antagonism between metiamide and pentagastrin. International Symposium on Histamine $\mathrm{H}_{2}$-receptor Antagonists, pp. 219-224. Edited by C. J. Wood and M. A. Simkins, Smith, Kline and French: Welwyn Garden City.

Brimblecombe, R. W., Duncan, W. A. M., Durant, G. J., Emmett, J. C., Ganellin, C. R., and Parsons, M. E. (1975). Cimetidine-a non-thiourea $\mathbf{H}_{2}$-receptor antagonist. Journal of International Medical Research, 3, 86-92.

Burland, W. L., Duncan, W. A. M., Hesselbo, T., Mills, J. G., and Sharpe, P. C., Haggie, S. J., and Wyllie, J. H. (1975). Pharmacological evaluation of cimetidine, a new histamine $\mathrm{H}_{2}$-receptor antagonist, in healthy man. British Journal of Clinical Pharmacology, 2, 481-486.

Cano, R., Isenberg, J. I., and Grossman, M. I. (1976). Cimetidine inhits caffeine-stimulated gastric acid secretion in man. Gastroenterology, 70, 1055-1057.

Carter, D. C., Forrest, J. A. H., Logan, R. A., Ansell, I., Lidgard, G., Heading, R. C., and Shearman, D. J. C. (1976). Effect of the histamine $\mathrm{H}_{2}$-receptor antagonist, cimetidine, on gastric secretion and serum gastrin during insulin infusion in man. Scandinavian Journal of Gastroenterology, 11, 565-570.

Grossman, M. I. (1961). Stimulation of secretion of acid by distention of denervated fundic pouches in dogs. Gastroenterology, 41, 385-390.

Grossman, M. I. (1962). Secretion of acid and pepsin in response to distention of vagally innervated fundic gland area in dogs. Gastroenterology, 42, 718-721.

Grötzinger, U., Bergegårdh, S., and Olbe, L. (1977a). The effect of fundic distension on gastric acid secretion in man. Gut, 18, 105-110.

Grötzinger, U., Bergegårdh, S., and Olbe, L. (1977b). The effect of atropine and proximal gastric vagotomy on the acid response to fundic distension in man. Gut, 18, 303-310.

Grötzinger, U., Bergegårdh, S., and Olbe, L. (1977c). Effects of fundic distention on pentagastrin-stimulated gastric acid secretion in man. Gastroenterology, 73, 447-452.

Grötzinger, U., Rehfeld, J. F., and Olbe, L. (1977d). ls there an oxyntopyloric reflex for release of gastrin in man? Gastroenterology, 73, 753-757.

Henn, R. M., Isenberg, J. I., Maxwell, V., and Sturdevant, R. A. L. (1975). Inhibition of gastric acid secretion by cimetidine in patients with duodenal ulcer. New England Journal of Medicine, 293, 371-375.

Hollander, D., Hussain, Z., and Sufi, A. M. (1975). Inhibition of nocturnal acid secretion in duodenal ulcer patients by an $\mathbf{H}_{2}$ histamine antagonist-cimetidine, a controlled double blind investigation. Clinical Research, 23, 481 A.

Knutson, U., and Olbe, L. (1973). The gastric acid response to sham feeding in duodenal ulcer patients after proximal selective vagotomy. (Abstract) Scandinavian Journal of Gastroenterology, 8, suppl. 20, 16-17.

Knutson, U., and Olbe, L. (1974a). Gastric acid response to sham feeding before and after resection of antrum and duo- denal bulb in duodenal ulcer patients. Scandinavian Journal of Gastroenterology, 9, 191-201.

Knutson, U., and Olbe, L. (1974b). The effect of exogenous gastrin on the acid sham feeding response in antrum-bulbresected duodenal ulcer patients. Scandinavian Journal of Gastroenterology, 9, 231-238.

Knutson, U., Olbe, L., and Ganguli, P. C. (1974). Gastric acid and plasma gastrin responses to sham feeding in duodenal ulcer patients before and after resection of antrum and duodenal bulb. Scandinavian Journal of Gastroenterology, 9, 351-356.

Konturek, S. J., Tasler, J., Obtutowicz, W., and Cieszkowski, M. (1976). Comparison of amino acids bathing the oxyntic gland area in the stimulation of gastric secretion. Gastroenterology, 70, 66-69.

Mayer, G., Arnold, R., Feurle, C., Fuchs, K., Ketterer, H., Track, N. S., and Creutzfedlt, W. (1974). Influence of feeding and sham feeding upon serum gastrin and gastric acid secretion in control subjects and duodenal ulcer patients. Scandinavian Journal of Gastroenterology, 9, 703-710.

Pounder, R. E., Williams, J. G., Russell, R. C. G., MiltonThompson, G. J., and Misiewicz, J. J. (1976). Inhibition of food-stimulated gastric acid secretion by cimetidine. Gut, 17, 161-168.

Richardson, C. T., Walsh, J. H., and Hicks, M. I. (1976). The effect of cimetidine, a new histamine $\mathrm{H}_{2}$-receptor antagonist, on meal-stimulated acid secretion, serum gastrin, and gastric emptying in patients with duodenal ulcer. Gastroenterology, 71, 19-23.

Shoemaker, R. L., Buckner, E., Spenney, J. G., and Sachs, G. (1974). Action of Burimamide, a histamine antagonist, on acid secretion in vitro. American Journal of Physiology, 226, 898-902.

Siegel, S. (1956). Nonparametric Statistics for the Behavioral Sciences. McGraw-Hill: New York.

Sjödin, L. (1976). Metiamide inhibits canine gastric acid secretion evoked by sham feeding. Scandinavian Journal of Gastroenterology, 11, 559-560.

Stenquist, B., Knutson, U., and Olbe, L. (1976). Gastric acid responses to sham feeding and modified sham feeding in duodenal ulcer patients. Scandinavian Journal of Gastroenterology, 11, Suppl. 38: 41.

Tepperman, B. L., Schofield, B., and Tepperman, F. S. (1975). Effect of Metiamide on acid secretion from isolated kitten fundic mucosa. Candian Journal of Physiology and Pharmacology, 53, 1141-1146.

Thjodleifsson, B., and Wormsley, K. G. (1975). Aspects of the effect of metiamide on pentagastrin-stimulated and basal gastric secretion of acid and pepsin in man. Gut, 16, 501-508.

Thompson, M. H., Albinus, M., Blair, E. L., Reed, J. D., and Venables, C. W. (1975). The interaction of cholingergic and histaminic blockades on the parietal cell: therapeutic possibilities (Abstract). British Journal of Surgery, 62, 158. 